\title{
Relationship between the red blood cell distribution width (RDW) and erythrocyte values in anemic and non-anemic cats
}

\section{Relação da amplitude de distribuição do diâmetro dos eritrócitos (RDW) com valores do eritrograma em gatos anêmicos e não anêmicos}

\author{
Paulo Henrique da Silva ${ }^{1}$; Cecília Braga Laposy ${ }^{2}$; Rogério Giuffrida ${ }^{2}$; \\ Marina Platzeck Chaves ${ }^{3}$; Maickon Willian de Freitas ${ }^{3}$
}

\begin{abstract}
Erythrocyte alterations require making decisions, guiding clinical conduct, determining prognoses, and choosing therapy options for diseases. Automated devices that can perform blood cell counts allow for calculation of amplitude distribution of erythrocytes red blood cell distribution width (RDW) and its fractions (RDW-CV and RDW-SD). It also evaluates quantitatively the heterogeneity of each erythrocyte, especially in the feline species where presence of anisocytosis is common, even under normal conditions. Contrary to human medicine where there has been universal acceptance of RDW, there are only a handful of veterinarians and laboratories that currently use this parameter as a diagnostic tool for differential laboratory diagnosis of anemia in veterinary medicine, possibly owing to unfamiliarity with the application. Faced with limited availability of information in scientific literature regarding RDW values for the domestic cat, this study aimed to associate RDW values with erythrocytes, hematocrit, hemoglobin, and mean corpuscular volume (MCV) in 407 adult cats of no defined pedigree $(n=218$ males and $\mathrm{n}=189$ females; 335 non-anemic and 72 anemic). In the present study, RDW-SD values in anemic cats were $20.4 \%$ above those considered normal, while RDW-CV values were $25.2 \%$ higher than those considered normal for the species. We concluded that interpretation of RDW values is an important tool for evaluating heterogeneity of erythrocytes with regard to anemia. Even in non-anemic animals, increased levels of RDW may suggest early erythrocyte alterations.
\end{abstract}

Key words: Feline, erythrocyte indices, hematology

\section{Resumo}

As alterações eritrocitárias demandam decisões e norteiam a conduta do clínico quanto ao prognóstico e a terapêutica de eventuais doenças. A utilização de equipamentos automatizados que fazem a contagem celular sanguínea permite o cálculo da amplitude de distribuição dos eritrócitos (RDW- red blood cell distribution width) e suas frações (RDW-CV e RDW-SD), para avaliar de forma quantitativa a heterogenicidade de cada eritrócito, em especial para a espécie felina, uma vez que é comum nestes animais a presença de anisocitose mesmo em condições normais. Ao contrário da medicina humana, em que ocorreu uma grande aceitação do RDW, na medicina veterinária ainda são poucos veterinários

\footnotetext{
M.e em Ciência Animal, Universidade do Oeste Paulista, UNOESTE, Presidente Prudente, SP, Brasil. E-mail: petbrazil@hotmail. com

2 Profs., Programa de Pós-Graduação em Ciência Animal, UNOESTE, Presidente Prudente, SP, Brasil. E-mail: claposy@unoeste. br; rgiuffrida@unoeste.br

${ }^{3}$ Discentes do Curso de Medicina Veterinária, UNOESTE, Presidente Prudente, SP, Brasil. E-mail: mari_platzeck@hotmail.com; maickon.wf@hotmail.com

* Author for correspondence
} 
e laboratórios que utilizam esse parâmetro como ferramenta diagnóstica para diagnóstico diferencial laboratorial das anemias, o que pode ser devido ao desconhecimento de sua aplicação. Diante da escassa informação disponível na literatura científica sobre os valores de RDW para o gato doméstico, este estudo propôs associar os valores obtidos de RDW com os eritrócitos, hematócrito, hemoglobina e volume corpuscular médio (VCM), de 407 gatos ( $\mathrm{n}=218$ machos, $\mathrm{n}=189$ fêmeas), sendo 335 não anêmicos e 72 anêmicos, adultos, sem raça definida. No presente estudo, os valores de RDW-SD dos gatos anêmicos aumentaram 20,4\% em relação aos considerados normais, enquanto o RDWCV apresentou valores $25,2 \%$ superiores aos considerados normais para a espécie. Conclui-se que, a interpretação dos valores de RDW é uma ferramenta importante para avaliação da heterogenicidade das hemácias frente à anemia. Mesmo em animais não anêmicos, os valores aumentados de RDW podem sugerir uma alteração eritrocitária precoce.

Palavras-chave: Felino, índices eritrocitários, hematologia

A hemogram or complete blood count is one of the most commonly requested examinations in clinical and surgical practices. The spinal response, which in various diseases is associated with alterations in red blood cell size, in conjunction with variations in blood hemoglobin concentration, presence of immature erythrocytes, and varying degrees of anisocytosis variables in peripheral blood is essential for providing clinical diagnoses and prognoses, as well as therapeutic procedures in the feline species (FLAIBAN; BALARIN, 2004).

Amplitude distribution of erythrocytes is a measure produced in automated hematology analyzers designed to provide reliable answers regarding degree of erythrocyte anisocytosis, without the need for microscopic evaluation. This index has been standardized in animal species, such as dogs (FLAIBAN; BALARIN, 2004; HODGES; CHRISTOPHER, 2011), horses (BALARIN et al., 2006), laboratory animals (YEOM et al., 2012), and cats. (RIOND et al., 2011). In humans, recent studies have shown that increased RDW can be considered as a risk factor for diseases such as cardiovascular diseases (TSELIOU et al., 2014), breast cancer (SERETIS et al., 2013), and pulmonary diseases (CELIK et al., 2015).

Studies have emphasized the correlation between macrocytosis and hypochromia and favorable bone marrow responses in different animal species (FELDMAN et al., 2000). Red blood cell distribution width (RDW) can provide first indication of bone marrow response in anemic dogs (NEIGER et al., 2002); however, only few studies have shown the correlation between RDW and other erythrogram values in the feline species. Thus, we aimed to verify the relationship between RDW and presence or absence of anemia in domestic cats.

The animals used in this study were treated at the Veterinary Hospital of the University of Oeste Paulista between January 2010 and December 2014. Of 407 domestic cats without defined pedigree selected ( $\mathrm{n}=218$ males, $\mathrm{n}=189$ females), they had an average age of $3.0( \pm 1.2)$ years; 41 male and 31 female cats were anemic.

The determination of RDW and its fractions, in addition to erythrocyte, hematocrit $(\mathrm{Ht})$, hemoglobin $(\mathrm{Hb})$, and mean corpuscular volume (MCV) values, were obtained using a POCH-100iV DIFF hematology analyzer (Sysmex do Brasil Indústria e Comércio LTDA, Curitiba/PR-Brazil).

Data were initially analyzed using the Kolmogorov-Smirnov test to verify normality of data. Student $t$-test was used to compare hematological analyses with sex of the animals, while chi-square test was used to evaluate the association of the RDW values (SD and CV) and presence or absence of anemia (PAGANO; GAUVREAU, 2004). All analyses were performed with a $5 \%$ level of significance using IBM SPSS v13.0 for Windows (IBM Corporation, Armonk, New York, USA). 
Animals that presented with erythrocyte, hematocrit, and/or hemoglobin values below those considered normal for feline species were classified as anemic (FELDMAN et al., 2000).
In the present study, an association was observed between RDW values (SD and CV) and presence of anemia in cats $(p<0.001)$. Odds ratio demonstrated that the animals that presented with higher RDWSD and RDW-CV values were 4.9 and 7.4 times more likely to be anemic, respectively (Table 1).

Table 1. Association between non-anemic and anemic animals, and values of RDW-SD and RDW-CV. Presidente Prudente, São Paulo, Brazil, 2015.

\begin{tabular}{|c|c|c|c|c|}
\hline & \multicolumn{2}{|c|}{ Anemia } & \multirow{2}{*}{ Odds Ratio $(95 \%$ CI) } & \multirow{2}{*}{ p-value* } \\
\hline & Present (\%) & Absent (\%) & & \\
\hline \multicolumn{5}{|c|}{ RDW-SD (fL) } \\
\hline Elevated & $46(11)$ & $88(22)$ & $4.966(2.897-8.514)$ & $<0.0001$ \\
\hline Normal & $26(6)$ & $247(61)$ & & \\
\hline \multicolumn{5}{|c|}{ RDW-CV (\%) } \\
\hline Elevated & $54(13)$ & $96(24)$ & $7.469(4.166-13.390)$ & $<0.0001$ \\
\hline Normal & $18(4)$ & $239(59)$ & & \\
\hline
\end{tabular}

CI: Confidence interval, ${ }^{*}$ Chi-square, ${ }^{*} p<0.05$.

Of 72 animals considered anemic (Table 1), $11.0 \%$ presented with significant increases in RDW-SD values and $13.0 \%$ presented with an increase in RDW-CV results, thereby highlighting heterogeneity of red blood cells in the presence of blood loss. In these animals, MCV did not present variations and remained within the normal range for the species. When comparing visual inspection of blood smears as a semi-quantitative method for characterizing anisocytosis in humans by automatic evaluation of RDW, Simel et al. (1988) concluded that extreme precision of this index was strongly suggestive of it being considered the "gold standard" for measuring degree of anisocytosis in red blood cells. Balarin et al. (2014) compared RDW and $\mathrm{MCV}$ in cats and verified a higher heterogeneity of red blood cells in animals that presented Ht outside the normal range for the species $(24-45 \%)$. In the present study, RDW-SD values in anemic cats were $20.4 \%$ higher than those considered normal, while RDW-CV was $25.2 \%$ higher when compared with the normal range for the species.
This study also found that a percentage of nonanemic animals presented with elevated RDW-SD (22.0\%) and CV (24.0\%) values, which were not accompanied by changes in MCV. This suggests that RDW may represent an erythrocyte value for early identification of cases of masked anemia (e.g., dehydration). It has been suggested in several human medical studies (RIEDL et al., 2014; TSELIOU et al., 2014; SALVAGNO et al., 2015) that such alterations may be due to other diseases in addition to anemia masked by dehydration; this remains unproven in domestic species (GUGLIELMINI et al., 2013; SWANN et al., 2014). According to Salvagno et al. (2015), an increase in RDW reflects a breakdown in erythrocyte homeostasis involving both impaired erythropoiesis and survival of abnormal red blood cells. This could be attributed to a variety of underlying metabolic abnormalities such as shortening of telomere length, oxidative stress, inflammation, nutritional state, dyslipidemia, hypertension, erythrocyte fragmentation, and altered erythropoietin function. In these cases, reticulocyte 
count would be highly indicative of an observable spinal response; as the study was retrospective, this determination was not performed.

Red blood cell distribution width results obtained from this study (Table 2) on felines classified as non-anemic were in accordance with the values found by Riond et al. (2011); they determined mean values of RDW-SD (33.9 fL) and RDW-CV (16.6\%) in cats using the same hematology analyzer that we used in our experiment. Mean corpuscular values determined in this experiment as well as other parameters of normal erythrograms were within the normal range for adult cats, thereby corroborating the findings of Clinkenbeard and Meinkoth (2000). In our study, no statistical differences were verified between males and females when associating sex with RDW. This result is in agreement with the data observed by Monteiro (2010), in humans.

Table 2. Mean values and standard deviations of MCV, RDW-SD, and RDW-CV of 407 non-anemic and anemic adult cats. Presidente Prudente, 2015.

\begin{tabular}{lcccc}
\hline & \multicolumn{2}{c}{ Males } & \multicolumn{2}{c}{ Females } \\
\hline \multicolumn{1}{c}{ Variables } & Non-anemic & Anemic & Non-anemic & Anemic \\
\hline VCM (fL) & $42.03 \pm 4.06^{\mathrm{Aa}}$ & $45.39 \pm 7.93^{\mathrm{Aa}}$ & $41.69 \pm 3.58^{\mathrm{Aa}}$ & $41.43 \pm 4.26^{\mathrm{Ba}}$ \\
RDW-SD (fL) & $33.04 \pm 4.76^{\mathrm{Aa}}$ & $41.89 \pm 13.45^{\mathrm{Bb}}$ & $32.21 \pm 5.22^{\mathrm{Aa}}$ & $36.04 \pm 7.44^{\mathrm{Bb}}$ \\
RDW-CV (\%) & $16.02 \pm 2.32^{\mathrm{Aa}}$ & $20.42 \pm 4.23^{\mathrm{Bb}}$ & $15.67 \pm 2.06^{\mathrm{Aa}}$ & $19.10 \pm 3.95^{\mathrm{Bb}}$ \\
\hline
\end{tabular}

$\mathrm{MCV}=$ mean corpuscular volume, $\mathrm{RDW}=$ red blood cell distribution width

Means followed by different capital letters indicate significant differences between genders. Means followed by different lowercase letters indicate significant differences between non-anemic and anemic animals of a particular gender.

In conclusion, RDW is an important tool for studying erythrocyte responses. Even in non-anemic animals, increased levels of RDW may suggest early erythrocyte alterations.

The study (protocol number: 952) was approved by the Ethics Committee on Animal Use.

\section{References}

BALARIN, G. S.; BALARIN, M. R. S.; FLAIBAN, K. K. M. C.; MARUCHI, H. P. Estudo comparativo entre amplitude de variação dos eritrócitos (RDW) e o volume globular médio (VGM) em gatos. In: CONGRESSO BRASILEIRO DA ANCLIVEPA, 35., 2014, Belo Horizonte. Anais... Belo Horizonte: ANCLIVEPA, 2014. p. 1016-1018.

BALARIN, M. R. S.; LOPES, R. S.; KOHAYAGAWA, A.; LAPOSY, C. B.; FONTEQUE, J. H. Valores da amplitude de distribuição do tamanho dos eritrócitos (RDW) em equinos puro sangue inglês (PSI) submetidos a exercícios de diferentes intensidades. Brazilian Journal of Veterinary Research and Animal Science, São Paulo, v. 43, n. 5, p. 637-641, 2006.

CELIK, A.; AZCAN, E. T.; GÜNDES, A.; TOPUZ, M.; PEKTAS, I.; YESIL, E.; AYHAN, S.; KOSE, A.; CAMSARI, A.; CIN, V. G. Usefulness of admission hematologic parameters as diagnostic tools in acute pulmonary embolism. Kaohsiung Journal of Medical Sciences, Kaohsiung, v. 1, n. 3, p. 145-149, 2015.

CLINKENBEARD, K. D.; MEINKOTH, J. H. Normal hematology of the cat. In: FELDMAN, B. F.; FELDMAN, B. F.; ZINKL, J. G.; JAIN, N. C. Schalm's veterinary hematology. 5. ed. Philadelphia: Lippicott Williams \& Wilkins, 2000. p. 1064-1068.

FELDMAN, B. F.; ZINKL, J. G.; JAIN, N. C. Schalm 's veterinary hematology. 5. ed. Philadelphia: Lippicott Williams \& Wilkins, 2000. 1344 p.

FLAIBAN, K. M. C.; BALARIN, M. R. S. Estudo comparativo entre a amplitude de variação dos eritrócitos (RDW - Red Blood Cell Distribution Width) e o volume globular (VG), volume corpuscular médio (VCM) e a presença de anisocitose em extensão sanguínea em cães. Semina: Ciências Agrárias, Londrina, v. 25, n. 2, p. $125-$ 130, 2004. 
GUGLIELMINI, C.; POSER, H.; PRIA, A. D.; DRIGO, M.; MAZZOTTA, E.; BERLANDA, M.; LUCIANI, A. Red blood cell distribution width in dogs with chronic degenerative valvular disease. Journal of the American Veterinary Medical Association, Ithaca, v. 243, n. 6, p. 858-62, 2013.

HODGES, J.; CHRISTOPHER, M. M. Diagnostic accuracy of using erythrocyte indices and polychromasia to identify regenerative anemia in dogs. Journal of the American Veterinary Medical Association, Ithaca, v. 238, n. 11, p. 1452-1458, 2011.

MONTEIRO, L. Valores de referência do RDW-CV e do RDW-SD e sua relação com o VCM entre os pacientes atendidos no ambulatório do Hospital Universitário Oswaldo Cruz-Recife, PE. Revista Brasileira de Hematologia e Hemoterapia, São Paulo, v. 32, n. 1, p. 34-39, 2010.

NEIGER, R.; HADLEY, J.; PFEIFFER, D. V. Differentiation of dogs with regenerative and nonregenerative anaemia on the basis of their red cell distribution width and mean corpuscular volume. Veterinary Record, London, v. 150, n. 14, p. 431-434, 2002.

PAGANO, M.; GAUVREAU, K. Princípios de bioestatística. São Paulo: Pioneira Thomson Learning, 2004. 522 p.

RIEDL, J.; POSCH, F.; KÖNIGSBRÜGGE, O.; LÖTSCH, F.; REITTER, E. M.; EIGENBAUER, E.; MAROSI, C.; SCHWARZINGER, I.; ZIELINSKI, C.; PABINGER, I.; AY, C. Red cell distribution width and other red blood cell parameters in patients with cancer: association with risk of venous thromboembolism and mortality. PLoS One, San Francisco, v. 9, n. 10, e111440, 2014.

RIOND, B.; WEISSENBACHER, S.; HOFMANNLEHMANN, R.; LUTZ, H. Performance evaluation of the Sysmex pocH-100iV Diff hematology analyzer for analysis of canine, feline, equine, and bovine blood. Veterinary Clinical Pathology, Baton Rouge, v. 40, n. 4, p. 484-495, 2011.
SALVAGNO, G. L.; SANCHIS-GOMAR, F.; PICANZA, A.; LIPPI, G. Red blood cell distribution width: a simple parameter with multiple clinical applications. Critical Reviews in Clinical Laboratory Sciences, London, v. 52, n. 2, p. 86-105, 2015.

SERETIS, C.; SERETIS, F.; LAGOUDIANAKIS, E.; GEMENETZIS, G.; SALEMIS, N. S. Is red cell distribution width a novel biomarker of breast cancer activity? Data from a pilot study. Journal of Clinical Medicine Research, Québec, v. 5, n. 2, p. 121-126, 2013.

SIMEL, D. L.; DeLONG, E. R.; FEUSSNER, J. R.; WEINBERG, J. B.; CRAWFORD, J. Erythrocyte anisocytosis: visual inspection of blood films vs automated analysis of red blood cell distribution width. Archives of Internal Medicine, Chicago, v. 148, n. 4, p. 822-824, 1988.

SWANN, J. W.; SUDUNAGUNTA, S.; COVEY, H. L.; ENGLISH, K.; HENDRICKS, A.; CONNOLLY, D. J. Evaluation of red cell distribution width in dogs with pulmonary hypertension. Journal of Veterinary Cardiology, Amsterdam, v. 16, n. 4, p. 227-235, 2014.

TSELIOU, E.; TERROVITIS, J. V.; KALDARA, E. E.; NTALIANIS, A. S.; REPASOS, E.; KATSAROS, L.; MARGARI, Z. J.; MATSOUKA, C.; TOUMANIDIS, S.; NANAS, S. N.; NANAS, J. N. Red blood cell distribution width is a significant prognostic marker in advanced heart failure, independent of hemoglobin levels. Hellenic Journal of Cardiology, Athens, v. 55, n. 5, p. 457-461, 2014.

YEOM, S. C.; CHO, S. Y.; PARK, C. G.; LEE, W. J. Analysis of reference interval and age-related changes in serum biochemistry and hematology in the specific pathogen free miniature pig. Laboratory Animal Research, Chungbuk, v. 28, n. 4, p. 245-253, 2012. 
